\title{
Approach for Conductometric Flow Injection Analysis of the Salt Content in Food
}

\author{
Kiyoshi Matsumoto*, Koh-ichi Ishida*, and Yutaka Osajima* \\ * Department of Food Science and Technology, Faculty of Agriculture, \\ Kyushu University, Hakozaki Higashi-ku, Fukuoka 812
}

\begin{abstract}
A rapid and convenient method based on conductometry is applied to flow injection analysis for measuring salt content in food. The development of a flow system was investigated for determining the salt content in processed foods with added salt. A linear correlation between the peak conductivity and the salt content was obtained with high correlation coefficient $(r=0.9998)$. It is possible to analyze about 70 samples within an hour using the method, and the coefficient of variation for 10 successive injections was $0.22 \%$. The proposed method is very simple and rapid, and it requires no amount of skill in measuring.
\end{abstract}

Salt has been added to many foods as seasoning, salting agent for preservation, and as an agent to improve quality.

Recently, consumers are paying much attention to salt content in food as an improtant component affecting human health. For these reasons, it is increasingly important to determine salt content in food.

Argentometry has been commonly used for the determination of salt content in processed foods with added salt. The method, however, is not only tedious and time-consuming but also produces waste fluid containing heavy metal.

In recent years, ion selective electrode method and atomic absorption spectrophotometry have been used for this purpose. These are powerful and useful methods, but not sufficient for qualty control and standardization of food at the food industry site, because at this site a simple and rapid method is required as well as an accurate and precise one.

A rapid and convenient method based on conductometry has been developed for measuring salt content in food by OsaJIMA, et al ${ }^{(1)-4)}$. The theory of the method is based on the fact that the conductivity of properly diluted sample solution strongly correlaes to the salt content of original sample if the salt content of a sample is relatively high and yet the concentration of other coexistent electrolytes is low and nearly constant.

Seasonings, such as worcester sauce and soy sauce, contain relatively high level of salt and, moreover, the equivalent ion conductivities of sodium and chloride ions are relatively high compared with those of other ions. The conductivity of the properly diluted seasoning is assigned to the salt content in the original sample. Namely, a linear relationship was set up between salt content and the conductivity of the properly diluted sample. To increase the speed and simplicity of measurement, it is desirable to adopt a continuous-flow technique.

Continuous-flow sample processing in routine analyses using flow injection analysis (FIA) is now widely applied ${ }^{5) \sim 7}$. The combination of FIA and the electrochemical method has been investigated for measuring the organic acid content of citrus fruits ${ }^{8)}$. The application of the electrochemical method to FIA will propose a powerful method for measuring the salt content of food.

This paper proposes the application of the conductometric method developed by Osajima, et al. to the FIA method. Namely, the development of a flow system and the measuring conditions for pure salt system were investigated to determine salt content in soy sauce (12 20\% salt). 


\section{Materials and methods}

Conductance measurement equipment

The alternating current four-electrode method (controlled-potential) was used for conductance measurement. The equipment was outlined as described previously $y^{8)}$. The output voltage from the equipment had a linear range of $10^{-5}$ $\sim 10^{-4} \mathrm{~S}$.

\section{Flow-through four-electrode cell}

The cell was constructed with four pieces of platinum wire (i. d. $=1 \mathrm{~mm}$ ); the probe electrodes (PE-PE') and the current-carrying electrodes $\left(\mathrm{CE}-\mathrm{CE}^{\prime}\right)$. A more detailed description of the cell design was given in the previous paper ${ }^{8}$. The cell constant was estimated to be $5.555 \mathrm{~cm}^{-1}$ regardless of the flow rate of the solution.

\section{Flow system}

A schematic diagram of the flow system is shown in Fig. 1. The carrier solution (deionized water) in the reservoir was carried by a micro-tube pump through an air-damper, a sample injection valve (6-way switching valve) and a mixing coil $\left(\mathbf{M C}_{1}\right)$, and transported to a flow-through four-electrode cell and finally to a waste tank. A back pressure tube was set just after the flow-through cell to promote an air-damper effect and to eliminate the occurance of bubbles in the line. A 10channel micro-tube pump was used as an automatic diluter. One channel was allotted for original sample solution and the others were for deionized water. All channels were

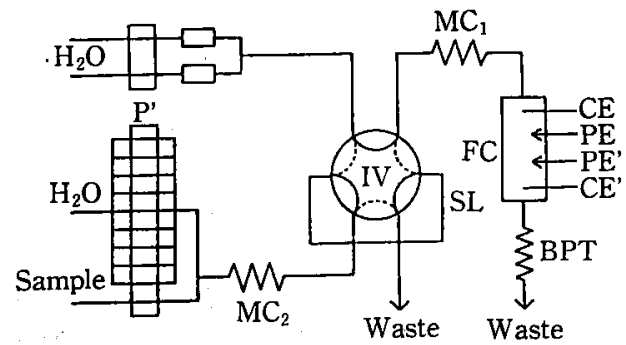

Fig. 1 Schematic flow diagram of FIA

$\mathrm{P}, \mathrm{P}^{\prime}$, micro-tube pump; $\mathrm{D}$, air damper; IV, injection valve; $\mathrm{SL}$, sample loop; $\mathrm{MC}$, mixing coil; FC, flow-through cell; BPT, back pressure tube; $C E, C E^{\prime}$, current-carrying electrodes; $\mathrm{PE}, \mathrm{PE}^{\prime}$, probe electrodes. joined at one point and mixed thouroughly in a mixing coil $\left(\mathrm{MC}_{2}\right)$. The automatically diluted sample (10-fold dilution) was transported into a sample loop and injected into the carrier stream by switching the valve. The injected sample was further diluted in the mixing coil $\left(\mathrm{MC}_{1}\right)$ and transported into a flow-through four-electrode cell. A teflon tube (i. d. $=1 \mathrm{~mm}$ ) was used for line unless otherwise noted.

\section{Reagents}

A reagent grade of potassium chloride was recrystallized twice from water. Deionized water, with conductivity less than $5 \mu \mathrm{S} \cdot \mathrm{cm}^{-1}$, was used throughout. All other chemicals were of analyltical reagent grade and were used without further purification.

\section{Procedures}

The conductance cell and the mixing coils were maintained at $(20 \pm 0.2){ }^{\circ} \mathrm{C}$ in a temperature-controlled room $\left[(20 \pm 1)^{\circ} \mathrm{C}\right]$. The preparation of sodium chloride standard solution was performed according to the method shown in the literature ${ }^{9)}$.

\section{Estimation of dilution ratio}

The standard solution of $15 \%(\mathrm{w} / \mathrm{w}) \mathrm{NaCl}$ was diluted in various dilution ratios. Each resulting solution was let flow as carrier solution separately and the conductivity of the solution was measured. A plot of conductivity $\imath s$. dilution ratio was obtained and used as a calibration curve. Each dilution ratio through out this experiment was estimated by the value of peak conductivity by using this calibration curve.

\section{Results and discussion}

\section{Dilution ratio}

Because the salt content in soy sauce is relatively high level $(12 \sim 20 \%(\mathrm{w} / \mathrm{w}))$, it is desirable to dilute the sample properly in order to fit the measuring range of the conductance equipment $\left(50 \sim 600 \mu \mathrm{S} \cdot \mathrm{cm}^{-1}\right)$. If the solutions containing $12 \sim 20 \%(\mathrm{w} / \mathrm{w})$ of $\mathrm{NaCl}$ were diluted 800 times by water, the conductivities of the resulting solutions would be $308-557 \mu \mathrm{S}$. $\mathrm{cm}^{-1}$. As a result, dilution ratio not less than 1:800 was necessary for this method. However, dilution ratio (dispersion) of FIA is about 1:100 at the most. Accordingly, the original 


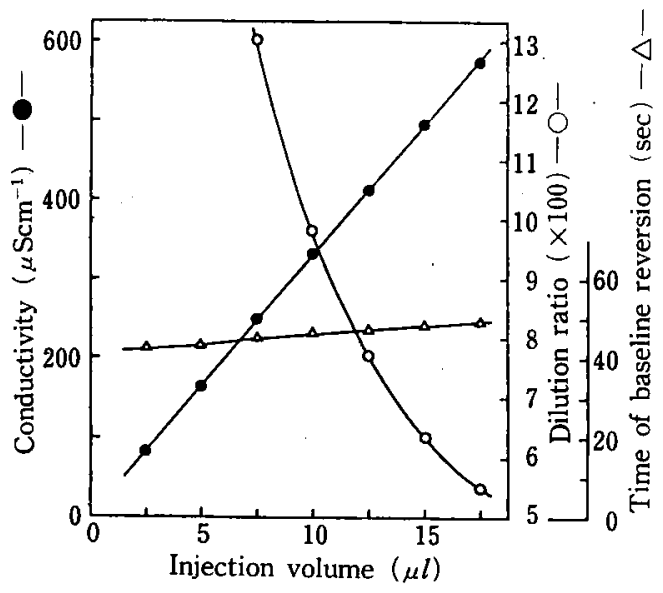

Fig. 2 Effect of injection volume on conductivity $(\bullet)$, dilution ratio $(0)$ and baseline reversion time $(\Delta)$.

Sample: $15 \%(\mathrm{w} / \mathrm{w}) \mathrm{NaCl}$ solution (10 times diluted)

Flow rate: $3.85 \mathrm{ml} / \mathrm{min}$

Mixing coil: tube diameter $=1.0 \mathrm{~mm}$, tube length $=100 \mathrm{~cm}$, coi diameter $=$ $13 \mathrm{~mm}$

sample was preliminary diluted by an automatic diluter before being forced into the sample loop.

Injection volume
The injection volume of a sample is an important factor affecting dilution ratio or dispersion. Generally, the less injection volume the larger is the dispersion, but bad reproducibility of response will appear in the case of extremely little volume. Fairly large dispersion, relatively high response within the measuring range of the equipment and short measuring time are desirable. The effect of the injection volume on the dilution ratio, the peak response and the base-line reversion time is shown in Fig. 2. A $10-$ fold diluted solution of $15 \%(w / w) ~ N a C l$ was used as a sample solution, and other conditions were noted in the legends of Fig. 2. A linear relationship was obtained between the peak response and the injection volume, and the dilution ratio decreased rapidly with increasing injection volume. The change of baseline reversion time was small and negligible. When considering that the dilution ratio not less than 1:800 and higher peak response within the measurable range is desirable, the optimum injection volume was $11 \sim 12 \mu l$. Concerning the sample loop construction, the volume of the fabricated sample loop was 11.3 $\mu l$.

\section{Mixing coil}

The injected sample was mixed and diluted with carrier solution during flow-through in

Table 1 Effect of mixing coil on dilution ratio, base-line reversion time and coefficient of variation

\begin{tabular}{ccccccc}
\hline$d_{\mathrm{t}}(\mathrm{mm})$ & $L(\mathrm{~cm})$ & $V\left(\mathrm{~cm}^{3}\right)$ & $\kappa\left(\mu \mathrm{Scm}^{-1}\right)$ & $D$ & $t_{\mathrm{b}}(\mathrm{sec})$ & \multicolumn{1}{c}{$\mathrm{C} . \mathrm{V} .(\%)$} \\
\hline 0.5 & 200 & 0.39 & 355.1 & 911 & 38 & 0.75 \\
0.5 & 150 & 0.30 & 588.6 & 532 & 37 & 0.50 \\
0.5 & 100 & 0.20 & 717.1 & 433 & 35 & 0.66 \\
0.5 & 50 & 0.10 & 813.8 & 375 & 33 & 0.49 \\
1.0 & 200 & 1.57 & 296.3 & 1106 & 65 & 0.20 \\
1.0 & 150 & 1.18 & 315.5 & 1038 & 58 & 0.17 \\
1.0 & 100 & 0.79 & 367.1 & 880 & 49 & 0.28 \\
1.0 & 50 & 0.39 & 480.9 & 654 & 41 & 0.11 \\
2.0 & 200 & 6.28 & 220.6 & 1507 & 184 & 0.30 \\
2.0 & 150 & 4.71 & 246.3 & 1305 & 153 & 0.51 \\
2.0 & 100 & 3.14 & 329.7 & 990 & 115 & 0.41 \\
2.0 & 50 & 1.57 & 549.5 & 571 & 81 & 0.44 \\
\hline
\end{tabular}

$d_{\mathrm{t}}$ : Tube diameter, $L:$ Tube length, $t_{\mathrm{b}}$ : Base-line reversion time, $D:$ Dilution ratio, $\kappa:$ Conductivity.

Sample: $15 \%(\mathrm{w} / \mathrm{w})$ solution (10 times diluted), Flow rate: $3.98 \mathrm{ml} / \mathrm{min}$, Injection volume: $11.3 \mu l$ 
the mixing coil $\left(\mathrm{MC}_{1}\right)$. It is necessary to mix the sample uniformly with carrier solution in order to get stable and reproducible data. The effects of tube diameter and tube length were investigated to get optimum conditions for mixing coil. A 10-fold diluted solution of $15 \%$ (w/w) $\mathrm{NaCl}$ was used as a sample solution, and flow rate and injection volume were $3.98 \mathrm{ml} / \mathrm{min}$ and $11.3 \mu l$, respectively. Teflon tubes with an inner diameter of $0.5,1.0$ and $2.0 \mathrm{~mm}$ were used as mixing coils and wound around polycarbonate tubes. The diameter of the polycarbonate tube (corresponding to the mixing coil diameter) scarcely influenced the dispersion, so the tube with $13 \mathrm{~mm}$ diameter was used. The results are shown in Table 1 . When the tubes with equal diameter were used, the dispersion became larger with increasing the tube length. In case of equal tube length, the larger the tube diameter, the larger the dispersion. When the coils with equal volume but different inner diameter were used, the smaller inner diameter produced larger dispersion and shorter base-line reversion time. The coeff cients of variation, though relatively small variations were observed by slight change of measuring temperature, were nearly constant for each group of same inner diameter tubes. When mixing coils with 0.5 and $2.0 \mathrm{~mm}$ (i.d.) were used, disturbances of the sample zone were caused at the point of joint by the difference of tube diameter between the stream line (i. d. $=1 \mathrm{~mm}$ ) and mixing coils, and relatively large variations were observed. The optimum mixing coil was jndged to be that with tube diameter of $1 \mathrm{~mm}$ and tube length of $100 \sim 150 \mathrm{~cm}$.

\section{Flow rate}

The dispersion of the injected sample is drastically changed by flow rate of carrier solution. On the other hand, if equal volume of sample were injected, the measuring time would be shortened with increasing flow rate. The effects of flow rate on the peak response, dilution ratio and base-line reversion time were investigated under the conditions set above and shown in Fig. 3. Larger dispersions and lower peak responses and shorter base-line reversion times were produced with increasing flow rate up to $4.3 \mathrm{ml} / \mathrm{min}$. The change of peak shape

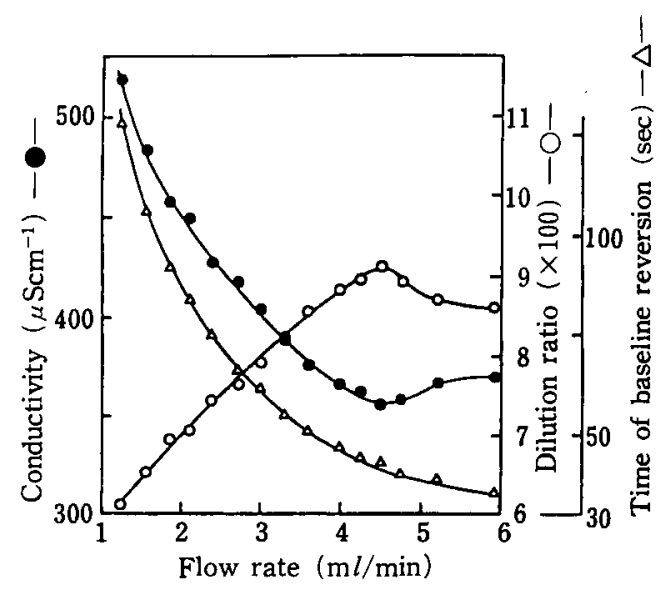

Fig. 3 Effect of flow rate on conductivity ( $\bullet$, dilution ratio $(0)$ and base-line reversion time $(\Delta)$
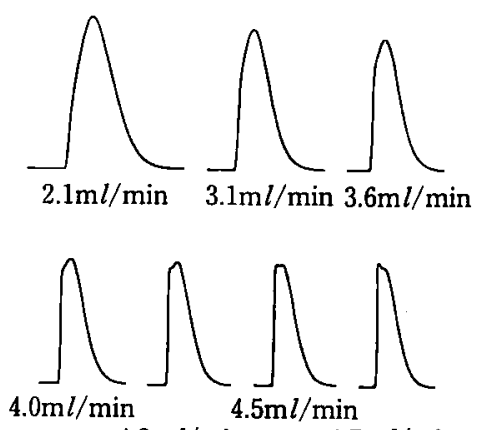

Fig. 4 Effect of flow rate on response curve

with flow rate was shown in Fig. 4. When the flow rate was faster than $4.3 \mathrm{ml} / \mathrm{min}$, the shape of response peak came to be distorted by the disturbance of sample zone which was caused by the difference of the tube diameter between stream line (i.d. $=1 \mathrm{~mm}$ ) and flowthrough cell (i.d. $=2 \mathrm{~mm}$ ). The distortion of the shape was increased and discrimination of a real peak value became difficult in the range of $4.3 \sim 4.7 \mathrm{ml} / \mathrm{min}$. The most desirable flow rate was judged to be $3.8 \mathrm{ml} / \mathrm{min}$, in consideration of dilution ratio ( $\geqq 800$ ), the relatively high reproducibility in the measurable range, the short measuring time, and good shape of response peak.

As a result, it is desired that dispersion (dilution ratio) and measuring time are decided 
by a measure of the injection volume and flow rate, respectively. The optimum running conditions were set as follows: injection volume, $11.3 \mu \mathrm{l}$; flow rate, $3.8 \mathrm{ml} / \mathrm{min}$; tube diameter of mixing coil, $1 \mathrm{~mm}$; tube length of mixing coil, $100 \mathrm{~cm}$; and coil diameter of mixing coil, $13 \mathrm{~mm}$. When a 10-fold diluted solution of $15 \%(\mathrm{w} / \mathrm{w}) \mathrm{NaCl}$ was measured under these conditions, the overall dilution ratio was $1: 885$ and coefficient of variation was less than $0.2 \%$.

\section{Diluter}

To attain a large dilution ratio, preliminary dilution was essential. Almost all commercial diluters are chamber type and troublesome to change sample. A new type of diluter was developed and the characteristics were examined. The system was described in the section of Materials and Methods and shown in Fig. 1. An uniform mixing was not achieved by simple combine of original sample solution and water. It is necessary to accelerate the radial dispersion in the tube in order to achieve uniform mixing. A mixing coil $\left(\mathrm{MC}_{2}\right)$ which was wound around the polycarbonate tube (i. d. $=25 \mathrm{~mm}$ ) was attached just after the confluence and the efficiency of the coil was investigated. A $15 \%$ $(\mathrm{w} / \mathrm{w}) \mathrm{NaCl}$ solution was used as a sample and

Table 2 Effect of mixing coil length of diluter on coefficient of variation

\begin{tabular}{lccc}
\hline \hline Tube length & $1 \mathrm{~m}$ & $3 \mathrm{~m}$ & $5 \mathrm{~m}$ \\
\hline & 374.5 & 371.8 & 373.2 \\
& 373.2 & 371.8 & 373.2 \\
& 371.8 & 373.2 & 373.2 \\
& 374.5 & 374.5 & 373.2 \\
& 377.3 & 373.2 & 373.2 \\
& 373.2 & 373.2 & 374.5 \\
& 377.3 & 375.9 & 374.5 \\
& 373.2 & 374.5 & 373.2 \\
& 373.2 & 373.2 & 371.8 \\
& 367.7 & 371.8 & 373.2 \\
\hline Average & 373.6 & 373.3 & 373.3 \\
S. D. & 2.60 & 1.28 & 0.72 \\
C. V. (\%) & 0.70 & 0.34 & 0.19 \\
\hline & \multicolumn{3}{c}{$\left(\mu \mathrm{Scm}^{-1}\right)$}
\end{tabular}

S. D.: Standard deviation

C. V.: Coefficient of variation

Tube diameter $=1.0 \mathrm{~mm}$

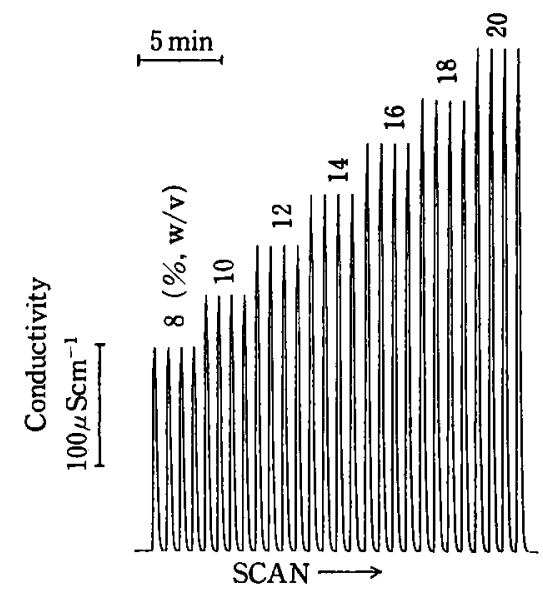

Fig. 5 Typical response curve of FIA

optimum running conditions described above are applied. As shown in Table 2, the coeffi cients of variation of the peak response were less than $0.4 \%$ and $0.2 \%$ for the coil lenght of $3 \mathrm{~m}$ and $5 \mathrm{~m}$, respectively. The value of response peak and the coefficient of variation agree well with those obtained by a 10-fold diluted $15 \%(\mathrm{w} / \mathrm{w}) \mathrm{NaCl}$ solution. An uniform dilution in the ratio 1:10 was achieved by this dilution system, and the variation by the diluter was virtually zero.

Responses and other characteristics

Typical response curves obtained under the optimum conditions are shown in Fig. 5. Sharp peaks were produced with a linear relationship to the $\mathrm{NaCl}$ concentration, and no distortion of the base-line was observed. A correlation coefficient between peak conductivity and $\mathrm{NaCl}$ concentration was 0.9998 . The reproducibility for 10 successive injections at a level of $15 \%$ (w/w) $\mathrm{NaCl}$ was $0.22 \%$ (C. V.), and 70 samples could be analyzed within an hour.

\section{Conclusion}

The developed conductometric FIA system is useful to measure salt content in processed foods with added salt. This method is very simple, rapid (70 samlpes/h) and requires no amount of skill in measuring. The precision is as high as batch system. The stream line and flow-through cell are easily cleaned by letting a detergent flow. The system might 
be applicable for many kinds of foods by changing the dilution ratio of diluter. The application of this FIA system to soy sauce and worcester sauce will be seen in the following paper.

\section{References}

1) Okayama, K., Matsumoto, K., Harada, S., Sakane, Y. and Osajima, Y. : Nippon Syokuhin Kogyo Gakkaishi, 26, 383 (1979).

2) Okayama, K., Matsumoto, K., Yamamoto, M. and Osajima, Y. : Nippon Syokuhin Kogyo Gakkaishi, 27, 40 (1980).

3) Okayama, K., Matsumoto, K., Yамamoto, M. and Osajıma, Y. : Nippon Syokuhin Kogyo Gakkaishi, 27, 179 (1980).

4) Osajima, Y. : Nippon Syokuhin Kogyo Gakkaishi, 28, 608 (1981).

5) Ruzicka, J. and Hansen, E. H. : Anal. Chim. Acta, 99, 37 (1978).

6) Ruzicka, J. and Hansen, E. H. : Chemtech., 756 (1979).

7) Stewart, K. K. : Anal. Chem., 55, 931A(1983).

8) Matsumoto, K., Ishida, K, Nomura, T. and Osajima, Y. : Agric. Biol. Chem., 48, 2211
(1984).

9) Nippon Syokuhin Kogyo Gakkai, Syokuhin Bunsekiho Hensyu Tinkai ed. "Syokuhin Bunsekiho" (Kohrin Co., Tokyo), p. 368, (1982).

(Received Jun. 22, 1985)

$$
\begin{gathered}
\text { 食品中食塩含量の電導度検出フローインジェク } \\
\text { ション分析へのアプローチ } \\
\text { 松本 清*・石田耕一* }{ }^{*} \text { 筬島 豊 }{ }^{*} \\
\text { (*九州大学農学部食糧化学工学科) }
\end{gathered}
$$

食品中の食塩含量測定のために，電導度法に基礎を固 く迅速・簡便な方法をフローインジェクション分析法に 適用した. 食塩添加加工食品中の食塩含量を測定するこ とを目指して，フロー系の開発を検討した．ピーク導電 率と食塩含量との間汇は相関係数 0.9998 の良好な直線 関係が成立した．本法を用いることにより，1時間当た り 70 試料を分析することが可能であり，10回の連続分 析に対する変動釈数は $0.22 \%$ であった. 本法は極めて簡 便・迅速であり，測定に何ら熟練を要しない。 